УДК 780.616.432:78.071.1(100=161.2)

DOI:

Соломія Баранська, студентка філологічного факультету Дрогобицького державного педагогічного університету імені Івана Франка

Присвячуємо всім полеглим за Украӥну в новому тисячолітті

\title{
НЕБЕСНА СОТНЯ ЯК СИМВОЛІЧНО-САКРАЛЬНА ФОРМУЛА МАЙДАННОЇ ПОЕЗІї
}

Статтю присвячено історії народження, розвитку й поширення знакового концептуального образу украӥнської мовосвідомості “Небесна Сотня", дослідженню мовностилістичних особливостей словакониепту.

Зазначено, щзо поезія Майдану - унікальне явище не тільки в украйнській літературній площині, а й у багатьох інших -ментальній, духовній, сочіальній, лінгвостилістичній. Це твори про боротьбу, про Майдан як символ нескореності й віри та про загиблих - щирі, відчайдушні й болючі, вони заслуговують бути увічненими.

Зроблено узагальнення, щуо Небесна Сотня - ие блискуча, лаконізована до двох слів образноконцептуальна й символічно-сакральна лінгвопоетична формула, знаковий лейтмотивний слово образ майданного дискурсу.

Ключові слова: майданна поезія; символ; сакральне; Небесна Сотня; поетонім; словообраз.

Jim. 13.

Solomiya Baranska, Student of the Philological Faculty Drohobych Ivan Franko State Pedagogical University

\section{THE HEAVENLY HUNDRED AS SYMBOL-SACRED FORMULA OF MAYDAN POETRY}

The article is devoted to the history of birth, development and spread of the symbolic conceptual image of Ukrainian self-consciousness "Heavenly Hundred", research of linguostylistic features of the wordconcept.

Maydan poetry is a unique phenomenon not only in Ukrainian literary plane, but also in many others such as: mental, spiritual, social and linguopoetic. They are works about struggle, about Maydan as a symbol of incontinence and faith and about the dead. They're sincere, desperate and painful, they deserve to be immortalized.

Heavenly Hundred is a brilliant, laconized up to two words, figuratively-concepted formula that has became acceptable in the national and even world scale.

The purpose of our research is to investigate the figuratively-lexical and conceptual features of the symbolicsacred phenomenon "Heavenly Hundred" taking into account the moments of the text integrity, the authors'manners and the broad context of the creativity of the authors of Maydan poetry. The task is to single out the dominant wordconcepts (mega-images); to determine the spectrum of their semantic-stylistic, symbolic and associative increments (Heavenly Hundred, Angels' Hundred, Sacred Hundred, Heavenly Brothers' Hundred, Hundred of Unconquered Heroes) on the basis of component analysis. The history of birth, development and spread of the symbolic conceptual image of Ukrainian lingua-consciousness "Heavenly Hundred" is traced. The circle of its main associates is outlined and the artistic onomasticon of anthology is investigated.

Keywords: maydan poetry; a symbol; sacred; Heavenly Hundred; poetonym; a word-concept.

$\Pi$ остановка проблеми. Минуло чотири роки, відколи наше суспільство почало жити в новому вимірі, а слово майдан набуло сакрального значення й стало символом Свободи та Гідності. Історики намагаються зібрати факти, узагальнити й дати оцінку всього, що відбувається з нами. Але чи зможемо навіть за кілька десятиліть осмислити все пережите, усі емоції та почуття учасників Революції Гідності?

" $C$ час розкидати каміння і $€$ час його збирати", - сказано в Біблії. Камені, просякнута вогнем бруківка Майдану означають дуже багато для тих, хто був присутній на ньому фізично чи духовно. Вони стали символом захисту від сил тьми, символом прагнення верховенства істини, символом розбивання брехливого минулого.

Майдан інспірував вибух неймовірної творчої енергії, яка за ці роки вербалізувалася в десятках романів, повістей, новел, публіцистичних нарисів та в різноманітній медійній продукції.

Антологія майданівських віршів "Небесна Сотня" - унікальне явище не тільки в українській літературній площині, а й у багатьох інших - 


\section{НЕБЕСНАСОТНЯ ЯК СИМВОЛЧНО-САКРАЛЬНА ФОРМУЛА МАЙДАННОЇ ПОЕЗІ}

ментальній, духовній, соціальній, лінгвопоетичній. Ідею укласти антологію народило саме життя. Поетичні тексти з'являлися в Інтернеті, газетах, на листівках; ними рясно були всипані могили новітніх героїв, місця їхньої загибелі. Чимало віршів уже стали народними і втратили імена своїх “батьків”. Тексти у цій книзі - не тільки професійних письменників (знаходимо тут проникливі вірші Дмитра Павличка, Любові Проць, Мар'яни Савки, Дмитра Лазуткіна, Маріанни Кіяновської, Василя Махна, Олександра Ірванця, Юрія Іздрика, Сашка Лірника), а й звичайних українців, які написали перший i, можливо, останній вірш у своєму житті. Та твори й одних, й інших про боротьбу, про Майдан як символ нескореності й віри та про загиблих - щирі, відчайдушні й болючі, вони заслуговують бути увічненими в наступних виданнях.

Мета статті. Дослідити образно-лексичні й концептуальні особливості символічносакрального феномену "Небесна Сотня" 3 урахуванням моментів текстової цілісності, авторської манери та широкого контексту творчості авторів майданної поезії. Завдання полягає в тому, щоб виокремити домінантні словаконцепти (мегаобрази), визначити спектр їхніх семантико-стилістичних, символічних та асоціативних прирощень, головно ж простежити історію народження, розвитку й поширення знакового концептуального образу української мовосвідомості “Небесна Сотня" (авторство, іманентна сакральність, зв'язок 3 іншими стрижневими майданівськими образами), окреслити коло його основних асоціатів.

Виклад основного матеріалу. Їх назвали Небесною Сотнею - українців, які загинули в Києві на Майдані, вулицях Грушевського та Інститутській. Гинули за честь, за волю, за право бути Українцем і за свою Батьківщину. Українські Ангели віддали життя за правду, свободу, незалежність своєї держави і ціною жертовності засвідчили (всупереч усім обережним та поміркованим прагматоскептикам), що наш український дух незламний, а народ - нескорений. "Свята сотня", “Сотня небесних братів", “Солдати Майдану”, наші “Ангели сьогодення” навіки зайняли свої пости захисту українського народу на Майдані.

Небесна Сотня - це блискуча, лаконізована до двох слів образно-концептуальна й символічно-сакральна лінгвопоетична формула, що блискавично поширилася й стала прийнятною в загальнонаціональному й навіть світовому масштабі [9]. Довший час вважали, що іiі креаторами були медійники, хто саме - не могли назвати. Справді, журналісти підхопили надзвичайно вдалий і точний образний вислів, але вперше ці святі для кожного українця слова сказали не вони, а письменниця з Полтавщини Тетяна Домашенко, що вже довший час мешкає у м. Вишневому під Києвом. Дивовижною є й історія народження знакового для української етносвідомості образу. Ось як про це розповідає сама письменниця: “21 лютого на Майдані ми прощалися $з$ полеглими побратимами. Звучить мелодія “Пливе кача по Тисині...” Серце рветься від туги... Несуть труни 3 нашими героями. Оголошують: воїни такої-то сотні, воїни сотні такої... Раптом немов струмом мене пробило: “Боже, людоньки, та це ж уже Небесна Сотня! Небесна Сотня воїнів Христа 3 мечем Архистратига Михаїла"... Так на Майдані народилися перші рядки, а вдома до третьої ночі написала весь вірш. Уранці подзвонила у Львів моїй приятельці Анні Семенюк, голові проводу Організації патріотів України, прочитала цю молитву. Вона каже: "Негайно скидай в Інтернет". Але текст ще не був навіть надрукований, а я поспішала на панахиду в храм Юрія Переможця у нас у Вишневому, де поминали загиблих героїв. Там я "Небесну Сотню" уперше прочитала, а на панахиді були журналісти, і вони підхопили це визначення. I доки я доїхала до Майдану, вислів "Небесна Сотня" мене обігнав" $[3,16]$.

Небесна Сотня вирушала в Господні засвіти під тужливу “Пісню ангелів". Цей день, коли київське середмістя знемагало від чорної жалоби, стефаниківськими мазками лаконізував В. Шовкошитний: “22 лютого з Майдану просто на шоковані небеса несли Небесну сотню. Звучала потойбічна лемківська пісня “Пливе кача". "Герої не вмирають!" - скандував трагічно-переможний Майдан” [13, 399].

Небесна Сотня (Ангельська Сотня, Сотня свята, Сотня небесних братів, Сотня невпокорених героїв) - знаковий лейтмотивний образ майданної поезії, сакральний в імпліцитно-експліцитному вимірі, з обмеженою кількістю образних конституентів, що дозволяе зберегти художню унікальність і водночас універсальність, убезпечує від поетичної претензійності та розмитості $[10,93]$. "Небесна Сотня”, образно кажучи, дисциплінує текст, визначає його урочисто-драматичну, подекуди піднесено-трагедійну тональність, програмує відповідне образно-лексичне оточення (ангели, архангели, воля, герої, небесна варта, молитва, плач, стезя, дзвони, Господь) [Докл. Про це див.: 10].

Озирнись, хто возносить тобі похвалу, 
Хто воздвиг п'єдестал і лавровим вінком прикрашає:

Визнання лиш посмертно навіки дарує народ $-$ Олімп.

Прижиттєвих героӥв у вирі життя не буває [2, 53].

Прийде час, і осиплеться 3 грюкотом слави

Дуже боляче падати вниз з висоти піднебесся.

Подивися затверджений список “героїв” твоєї землі

I подумай: ставати у ряд зі всіма - справа честі? [2, 53].

У світлих зоряних просторах

Труба архангельська гуде.

3 архістратигом Михаїлом

Небесна Сотня в лаві йде [5, 14].

Небесна Сотня помирала за Свободу,

Їх душі з нами сорок днів живуть...

Й навічно залишилися з народом,

Який до волі прокладає путь [5, 46].

Жертовність, лицарство, реалізація націєзахисної місії - це стрижневі образносемантичні компоненти, що головно реалізуються в лейтмотивному словообразі.

Над нами, браття, від сьогодні

Вартує честь Небесна Сотня.

Стезя героїв незворотна -

У Вічність йде Небесна Сотня [5, 260].

Аби сакральний образ Небесної Сотні не покрився хрестоматійно-офіційним глянцем, 3 плином часу не втратив цілком реальних, живих драматичних обрисів, автори поетичних текстів добирають відповідне контекстне оточення, вибудовують влучні паралелі (перфоменс, гнів, огонь).

Небесна Сотня - не перфоменс,

Фундамент завтрашньому дню.

Вона на Київськім Майдані

Постала з гніву і вогню $[5,14]$.

"Небесна Сотня - це наш біль і наша гордість, це наші сльози і наш душевний щем вдячності за все, що вони зробили для нас. Та ця пам'ять і ці почування будуть тільки відчуттями, якщо ми не плекатимемо щодня, допоки б'ються наші серця, плоди, гідні висоти подвигу Героїв Майдану”, - ці проникливі слова Блаженнійшого Святослава найточніше відбивають палітру почуттів та переживань авторів антології, вербалізованих у концептуальному й сакральному словообразі "Небесна Сотня" [7, 8].

Ми ж тепер - незборимі,

3 нами - сила Господня:

Вічно нас берегтиме

Наша Ангельська Сотня [5, 280].

Майдан - це символ, ідея, заради яких люди пішли на смерть. Героїчна смерть Небесної Сотні, як зауважує кінорежисер I. Подольчак, - у якомусь сенсі ірраціональна. Ця смерть, окрім смерті тих, хто рятував поранених, не мала жодного обгрунтування 3 погляду тактичної чи стратегічної необхідності. Але... набула епічного сакрального виміру. Небесна Сотня стала новітнім українським міфом в часи аморфної Незалежності. Можливо, саме це й було вищою метафізичною метою сучасної української нації, втіленням волі через Майдан. Героїчна смерть надає осмисленості життю нації. Незаперечне й інше: жертовна смерть воїнів Небесної Сотні влила життєдайну кров у тіло немічної, вже майже агонізуючої нації, роздертої контроверсійними ідеологемами, надала сенсу й осмисленості національному Поступу і Чину.

У романі-репортажі 3. Филипчука читаємо: "Це був голос самого народу, і це був вихід із безвиході. I що головне: народ, який там зібрався у довгих протестах і надіях на краще життя, вже не боявся смерті. Повсталі зробили свій вибір. I вже побачили, що вмерти по-людськи з гідністю - це найвища нагорода, це реальні зміни i перемога в їхній довготривалій боротьбі.

I на підсвідомому рівні ввійшло передчуття досі незвіданого свята - вмерти героєм. Подібне переживали всі жертовні воїни, які боролися за справедливість і волю, незалежно від національності, країни, часу.

Майдан Незалежності осіяло натхнення, на українських борців за свої людські права глянули з безсмертя воїни світла" [12, 197 - 198].

Воїни Світла, Воїни Добра - таке узагальнене символічне найменування отримали не лише загиблі на Майдані, а й ті, хто віддав і продовжує віддавати своє життя на буремному Донбасі.

Висновки. Небесна Сотня - знаковий лейтмотивний образ дискурсу Майдану, цілком сакральний в імпліцитно-експліцитному вимірі, 3 обмеженою кількістю образних конституентів, що дозволяє зберегти художню унікальність і водночас свідчить універсальність, убезпечує від поетичної претензійності та розмитості. Концептуальний образ дисциплінує текст, визначає його урочисто-драматичну, подекуди піднесено-трагедійну тональність, програмує відповідне образно-лексичне оточення (ангели, архангели, воля, герої, небесна варта, молитва, плач, стезя, дзвони, Господь). Це може стати предметом майбутніх студій над феноменом дискурсу Майдану.

\section{ЛІТЕРАТУРА}

1. Воронюк Л. Майдан: український духовний 


\section{НЕБЕСНАСОТНЯ ЯК СИМВОЛІЧНО-САКРАЛЬНА ФОРМУЛАМАЙДАННОӤ ПОЕЗЇ̈}

прорив / Воронюк Леся // Небесна Сотня: антологія майданівських віршів. - Чернівці: Видавничий дім “Букрек”, 2014. - С. 5 - 7.

2. [94 дні]. Свромайдан очима ТСН. -К., 2015. - 171 с.

3. Дениско Г. Тетяна Домашенко: "Уже ніхто не знищить Україну в тобі, в мені, у кожному із нас" / Ганна Дениско // Слово Просвіти. - 2015. - Ч. 4 (29 січня). - С. 16.

4. Кочан I. Біблійні персонажі // Лінгвістичний аналіз тексту: Навч. посіб. - 2-ге вид., перероб. і доп. - К.: Знання, 2008. - С. 90-93.

5. Небесна Сотня: антологія майданівських віршів / упорядкув., передмова Л. Воронюк.- Вид. 2-ге, доповн. - Чернівці: Видавничий дім “Букрек”, 2014. - 400 с.

6. Небесна Сотня: антологія майданівських віршів/ упорядкув., передмова Л. Воронюк. - Чернівці Видавничий дім “Букрек”, 2014. -392 с.

7. Небесна сотня / К. Богданович, Х. Бондарева, Ю. Бухтоярова та ін.; упоряд.: О. Трибушина, I. Соломко; передмови Патріарха Філарета, о. Г. Коваленка, о. Святослава; худож.-оформлювач Л. П. Вировець. - Харків: Фоліо, 2014. - 206 с

8. Святослав Сумління нації / Святослав, Отець Глава Української Греко-Католицької Церкви // Небесна сотня / К. Богданович, Х. Бондарева, Ю. Бухтоярова та ін.; упоряд.: О. Трибушина, І. Соломко. - Харків: Фоліо, 2014. - С. 8 .

9. Стецик М. "Серце кожне карбує імення" (поетичний іменник героїв Майдану) / Марія Стецик. / / Рідне слово в етнокультурному вимірі: зб. наук. праць / Дрогобицький державний педагогічний університет імені Івана Франка. - Дрогобич: Посвіт, 2015. - С.246 262.

10. Стецик М. Хресна дорога. “П’ятнадцята стація” (поезія Майдану в сакральному вимірі) / Марія Стецик. // Науковий вісник Чернівецького університету: Зб. наук. праць. - Вип. 772. Романо-слов'янський дискурс. Чернівці: Видавничий дім “Родовід”, 2016. - С.91-98.

11. Руф Ю. Час революції / Юрій Руф. - Видавничий дім "Панорама", 2014.-112 с.

12. Филипчук 3. День і ніч навколо багаття / Зеновій Филипчук. - Львів : Апріорі, 2015. - 204 с.

13. Шовкошитний В. Боривітри: історичний роман / Володимир Шовкошитний. - Київ: Український пріоритет, 2014. -400 c.

\section{REFERENCES}

1.Voroniuk, L. (2014). Maidan: ukrainskyi dukhovnyi proryv [Public Square (Maydan): the the Ukrainian spiritual breakthrough]. Heavenly Hundred: Anthology of poetry of Public Square. Chernivtsi: Vydavnychyi dim "Bukrek", pp. 5 - 7.[in Ukrainian].

2. 94 dni. Yevromaidan ochyma TSN (2015). [94 days. The European Public Square in the vision of Television News Service]. Kyiv, 171 p.[in Ukrainian].
3. Denysko, H. (2015). Tetiana Domashenko: "Uzhe nikhto ne znyshchyt Ukrainu v tobi, v meni, u kozhnomu iz nas" ["No one will already ruin Ukraine in you, in me, in each of us"]. Slovo Prosvity. Part. 4 (January 29th), p. 16. [in Ukrainian].

4. Kochan, I. (2008). Bibliini personazhi [The Bible characters]. Linguistic analysis of the text: Educational manual the 2 nd edition, processed and supplement. Kyiv: Znannia, pp. 90 - 93. [in Ukrainian].

5. Voroniuk, L. (Ed.). (2014).Nebesna Sotnia: antolohiia maidanivskykh virshiv [Heavenly Hundred Anthology of poetry of Public Square]. The 2nd edition. Chernivtsi: Vydavnychyi dim "Bukrek", 400 p. [in Ukrainian].

6. Voroniuk, L. (Ed.). (2014). Nebesna Sotnia: antolohiia maidanivskykh virshiv [Heavenly Hundred Anthology of poetry of Public Square]. The 2nd edition. Chernivtsi: Vydavnychyi dim "Bukrek", 392 p. [in Ukrainian].

7. Bohdanovych, K., Bondareva, Kh. \& Bukhtoiarova, Yu. et al., (2014). Nebesna sotnia [Heavenly Hundred]. (Ed.).O. Trybushyna, I. Solomko; peredmovy Patriarkha Filareta, o. H. Kovalenka, o. Sviatoslava; khudozh.oformliuvach L. P. Vyrovets. Kharkiv: Folio, 206 p. [in Ukrainian].

8. Bohdanovych, K., Bondareva, Kh. \& Bukhtoiarova, Yu. et al. (2014). Sviatoslav Sumlinnia natsii. Sviatoslav, Otets i Hlava Ukrainskoi Hreko-Katolytskoi Tserkvy [Svyatoslav, The nation's consolation. Svyatoslav, Father and Head of the Ukrainian Greek Catholic Church]. Heavenly Hundred [Небесна сотня]. (Ed.). O. Trybushyna, I. Solomko. Kharkiv: Folio, p. 8. [in Ukrainian].

9. Stetsyk, M. (2015). "Sertse kozhne karbuie imennia" (poetychnyi imennyk heroiv Maidanu) ["The everyone's heart carves the name" (the poetic noun of the heroes of the Public Square)]. Native word in ethnocultural dimension. Drohobych Ivan Franko State Pedagogical University. Drohobych: Posvit, pp.246 - 262. [in Ukrainian].

10. Stetsyk, M. (2016). Khresna doroha. "P'iatnadtsiata statsiia" (poeziia Maidanu $v$ sakralnomu vymiri) [Fifteenth Stage (poetry of the Public Square in the sacred dimension)]. The Scientific Herald of Chernivtsi University: Collection of scientific works. Vol.772. Romano-Slavic Discourse.Chernivtsi: Vydavnychyi dim "Rodovid", pp.91 - 98. [in Ukrainian].

11. Ruf, Yu. (2014). Chas revoliutsii [Time of revolution]. Vydavnychyi dim "Panorama", 112 p. [in Ukrainian].

12. Fylypchuk, Z.(2015). Den i nich navkolo bahattia[The day and night around the fire]. Lviv: Apriori, 204 p. [in Ukrainian].

13. Shovkoshytnyi, V. (2014). Boryvitry: istorychnyi roman [Boryvitry: historical novel]. Kyiv: Ukrainskyi priorytet, 400 p. [in Ukrainian].

Стаття надійшла до редакції 04.05.2018

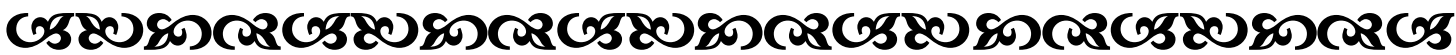

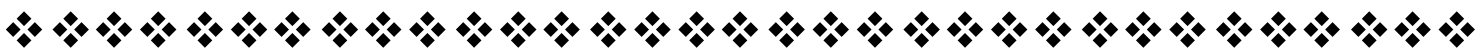

